\title{
Electrochemical conditioning of recycled flotation wastewater for flotation results improving
}

\author{
Marinela Panayotova ${ }^{1, *}$ and Vladko Panayotov ${ }^{1,2}$ \\ ${ }^{1}$ University of Mining and Geology, 1700 Sofia, Bulgaria \\ ${ }^{2}$ BAS - Technical Sciences, 1000 Sofia, Bulgaria
}

\begin{abstract}
Flotation of minerals, an important part of the chain of metals production for our society, needs huge amounts of water. This industry can contribute to the sustainable use of water and circular economy development by utilizing its own production wastewater. However, reuse of clarified water without additional treatment may cause worsening of flotation results. Electrocoagulation of this water with mild steel sacrificial anodes, complemented by electroflotation is able to decrease the chemical oxygen demand (COD) and dissolved organic carbon (DOC) of the treated water, i.e. to remove at least partially the residual organic reagents. For the studied case $66 \%$ of COD and nearly $32 \%$ of DOC were removed by electrocoagulation with mild steel electrodes at energy consumption of $0,458 \mathrm{kWh} / \mathrm{m}^{3}$. This warrants better results of lead-zinc flotation carried out with treated water, in comparison to the case of use of untreated water, and contributes to freshwater saving. Treated water ensured outcomes of lead-zinc flotation comparable to the results found at use of fresh tap water.
\end{abstract}

\section{Introduction}

Metals production starts with minerals mining and mineral processing. Both mineral processing fields, namely beneficiation (mineral dressing) and extractive metallurgy, require water. For example, it has been reported [1] that the water used in mineral processing accounts for the greatest water consumption in the copper production chain, in terms of total volume. In the mineral processing plants the treatment of minerals involves crushing and grinding, followed by flotation, classification and thickening, with all stages requiring water. Flotation is probably the biggest water consumer. Water consumption in the flotation of the mentioned copper ores reaches up to $3 \mathrm{~m}^{3} /$ ton [1]. According to Jennett and Wixson [2] about $6000 \mathrm{~L} / \mathrm{h}$ of water are required typically for ore grinding and flotation by a mineral processing plant treating polymetallic lead-zinc ores. According to other authors [3] ore beneficiation of nonferrous metals by flotation method requires $4-7 \mathrm{~m}^{3}$ of water for processing a ton of raw ore. Gunson and coauthors summarize that on average the $1,9-3,0 \mathrm{~m}^{3}$ of water are consumed per ton of ore processed [4].

* Corresponding author: marichim@mgu.bg 
Freshwater is crucial for sustainable life and development on our planet. However, in all its forms including ice caps, glaciers and permanent snow it represents $<3,454 \%$ of the global water [5]. It is estimated that 3,6 billion people reside in areas that are potentially water-scarce at least one month per year, and this population could increase to $4,8-5,7$ billion by 2050 . Water demand for goods manufacturing is expected to increase by $400 \%$ between 2000 and 2050 globally [6]. Dr. Michael Neumann, Chair of MWG-UNECE and Vice President EU Federation of Geologists said "a quarter of mining production, representing up to US\$ 50 bn in annual revenue, could be exposed to water shortages and drought by 2030 " [7]. Wastewater from mineral processing, when discharged directly into rivers or soil, might seriously endanger environment and human health $[8,9]$.

The sustainable use of water requires implementation of both legislative and technological measures for minimizing water use and for water treatment and reuse. As an example of legislative measures at the world level the announced International Decade (2018-2028) for Action, "Water for Sustainable Development", proclaimed by the Resolution 71/222 of the General Assembly of the UN (2017), can be pointed out. It includes also the water use in mining and mineral processing industry. More information on the legislative measures taken at continental and regional levels and related to mining and mineral processing industry can be found elsewhere [10]. The present paper deals with some technological measures.

Recycling and reuse of process waters is considered as one of most important solutions of the water shortage problem. Probably Canada is among the first countries with well developed mineral industry that has been recycling production water since 1970 - in the range from 50 to $75 \%$ of its process waters [11]. A large part of the water used in flotation becomes constituent of the tailings that are passed to the thickening stage. There and further in the filtration stage part of the water used in flotation is recovered. Further, the tailings are discharged into dams, permitting sedimentation of solids (fine mineral particles, some flocculated pollutants, some low soluble compounds formed) and separation of clarified water. This way, the maximum amount of clear water is recovered, which is aimed at returning to the flotation process in order to reduce the freshwater consumption. Another example is the Australian mineral industry that has managed to decrease its fresh water consumption from $3-1,8 \mathrm{~m}^{3} /$ ton of ore to around $0,79 \mathrm{~m}^{3} /$ ton of minerals $[12,13]$.

However, returning of only clarified wastewater back to flotation can slowly lead to disturbance in flotation process and deteriorate its results due to increased water salinity, accumulation of heavy metal ions and residual reagents, and increase in the amount of slimes $[14,15]$. For instance, the recycling of the untreated wastewater back to flotation has led to decrease of lead grade in lead concentrate by $62 \%$, compared to the concentrate obtained at fresh water using [11]. Presence of metal ions $\left(\mathrm{Cu}^{2+}, \mathrm{Fe}^{2+}, \mathrm{Zn}^{2+}, \mathrm{Ca}^{2+}, \mathrm{Mg}^{2+}\right)$ can cause activation and increase of reactivity of gangue mineral towards flotation collectors, resulting in decrease in metal recoveries. Residual flotation reagents (collectors - sulfurbearing, amines, carboxylate, as well as frothers and sulphidizing reagents) can disturb the flotation process and lead to simultaneous flotation of sulphides, oxides, and silicates thus resulting in obtaining of poor concentrates [11]. Presence of other organic compounds (flocculants, emulsifiers, etc.) as well as oil from spillages from the equipment increases the total organic matter content in the scavenging flotation and deteriorates the flotation results [16]. Chen and coauthors [17] studied the effect of reuse of mineral processing wastewater on flotation of sulfide minerals. They have found that the lead-concentrate water can better the galena flotation results, whereas the sulfur-concentrate water influenced negatively the flotation of galena in comparison to distilled water. Infrared analysis proved presence of residual collector on the surface of lead concentrate. Sandenbergh and Wei [18] have determined an increased concentration of zinc in the lead concentrate. 
That fact implies the loss in the collector selectivity arising due to the unwanted activation of sphalerite by copper, lead and silver ions available in the used recycled water. Recently Lin and co-authors [19] proposed to do changes in the amounts of added flotation reagents in order to respond to flotation variations caused by the accumulated flotation reagents in the recycled water. According to them, in this way flotation efficiency can be reliably and feasibly preserved while reusing process water. They decreased by over $10 \%$ the needed reagents amounts in the flotation process when using recycled water. The consumption of fresh water was decreased by $34,62 \%$ by the in-plant recycling of process water. The published results on the impact of use of recycled process water on flotation have not yet reached an agreement [20], however more of the studies find this to be disadvantageous $[21,22]$. Consequently, there is a need to remove at least partially residual flotation reagents from recycled process water in order to improve its quality and better the flotation results. However, most of studies used model wastewater instead of real process water and this may compromise results $[19,22]$.

Various techniques are applied to remove the pollutants from mineral-processing wastewater. Chemical coagulation and flocculation, followed by precipitation are widely used processes $[3,23]$ owed to their simplicity and effectiveness. The coagulation and flocculation processes remove not only suspended solids, but also improve the removal of heavy metals from treated water. However, the introduced counter-ions and residual chemicals may interfere with further flotation. Adsorption can efficiently remove flotation reagents present in low doses [3, 24] but further treatment of loaded adsorbent, with high water content, is needed. Chemical oxidation with sodium hypochlorite [25], sodium chlorate $\left(\mathrm{NaClO}_{3}\right)$ [26] and Fenton reagent [3, 27 ] has not proved enough effective and may result in secondary pollution [21]. The biodegradation is a cheap technology for treating flotation effluents. However, its application is limited due to the long treatment period [14] and the toxicity of some reagents to microbes [28, 29]. Ozonation has shown a potential to degrade flotation reagents in the waste process water $[21,30]$ but usually it has a low ozone-utilization rate and sometimes could be costly.

Recently the electrochemical treatment of process water, aimed at reuse in the flotation practice, has attracted the attention [31-35] and has been shown as promising to solve both environmental and technological problems.

Our experience with electrochemical removal of sulphates [36] and heavy metals [37] from mineral processing water and electrochemically aided flotation [38], together with the above brief discussion on the present situation with the water reuse, led us to the idea to study (i) the impact of use of recycled process water on lead zinc flotation results, (ii) the ability of electrochemical treatment to remove some organic pollutants (presented by integral parameters COD and DOC) from process water from a lead-zinc flotation, and (iii) the effect of the treatment on the flotation results when the treated water was used instead of fresh water.

\section{Electrochemical treatment basics - in brief}

In the electrochemical treatment process, electrodes are introduced in the treated liquid phase and current (mainly direct current - DC) is passed between the electrodes with the aid of an external source (a rectifier for DC). The chemical nature of the electrodes used determines the leading processes. When insoluble electrodes (and especially anode) are used, the main processes that may take place (depending on the water composition) are electrochemical reduction, direct or indirect electrochemical oxidation (EO) and electroflotation (EF). Use of electrodes with catalytic activity can enhance the electrooxidation [39]. When soluble electrodes are applied, the main processes are electrocoagulation (EC) and electroflotation (EF). 
In acidic medium the main cathodic reaction can be presented with the generalized equation (1):

$$
2 \mathrm{H}^{+}+2 e^{-} \rightarrow \mathrm{H}_{2}
$$

In neutral aqueous medium, the cathodic reaction is described by equation (2):

$$
2 \mathrm{H}_{2} \mathrm{O}_{(l)}+2 e^{-} \rightarrow \mathrm{H}_{2(\mathrm{~g})}+2 \mathrm{OH}_{(a q)}
$$

and by generalized reaction (3) if dissolved $\mathrm{O}_{2}$ is available in the water:

$$
\mathrm{O}_{2(\text { dis. })}+2 \mathrm{H}_{2} \mathrm{O}_{(l)}+4 e^{-} \rightarrow 4 \mathrm{OH}_{(a q)}
$$

The hydrogen gas produced at the cathode aids the movement of the flocs formed to the surface of the water as floating sludge.

If heavy metal or other ions with high enough standard oxidation-reduction potential present, they can be reduced directly, for example by reaction (4) for metal ions:

$$
M e^{n+}+n e^{-} \rightarrow M e_{(s)}^{o}
$$

Organic compounds can also be reduced by accepting electrons from the cathode or catching the hydrogen produced by reactions (1) or (2).

With soluble anodes (mainly iron, steel or aluminium) the anodic reaction can be expressed by the equation:

$$
M e^{o}(s)-n e^{-} \rightarrow M e^{n+}(a q)
$$

Produced metal ions combine (if cathodic and anodic compartments are not separated) with hydroxyl ions obtained by reactions (2) and (3) to in situ generate coagulants, as expressed by equation (6):

$$
\left.\mathrm{Me}_{(a q)}^{n+}\right)+n O H_{(a q)} \rightarrow \mathrm{Me}(\mathrm{OH})_{n(s)}
$$

The generated coagulating agent, i. e. $\mathrm{Me}(\mathrm{OH})_{\mathrm{n}(\mathrm{s})}$, ensures removal of different pollutants by several mechanisms, including charge neutralization, adsorption, precipitation and co-precipitation, pollutants (including emulsions) destabilization, bonding oil droplets and other pollutants to generated flocs, aggregation of the destabilized phases, and enmeshment. During or at the end of the process, flocs formed and "loaded" with the pollutants are removed either by sedimentation or by EF [31, 40 - 43].

With insoluble anodes the anodic process can be presented by the equation (7) [44]:

$$
2 \mathrm{H}_{2} \mathrm{O}_{(l)} \rightarrow 4 \mathrm{H}_{(a q)}^{+}+\mathrm{O}_{2(g)}+4 e^{-}
$$

and (in the presence of enough high concentration of chloride ions) also the reaction described by equation (8) can take place [45]:

$$
2 \mathrm{Cl}_{(\mathrm{aq})}^{-} \rightarrow \mathrm{Cl}_{2(\mathrm{~g})}+2 e^{-}
$$

Hypochlorous acid and $\mathrm{OCl}^{-}$ions (active chlorine), able to oxidize organic pollutants, may be further formed - equations (9) and (10):

$$
\begin{gathered}
\mathrm{Cl}_{2(a q)}+\mathrm{H}_{2} \mathrm{O} \rightarrow \mathrm{HClO}+\mathrm{Cl}^{-}+\mathrm{H}^{+} \\
\mathrm{HClO} \leftrightarrow \mathrm{ClO}^{-}+\mathrm{H}^{+}
\end{gathered}
$$

Under much higher voltage and / or current density conditions, reactions (7) and (8) can occur simultaneously with reaction (5) on the electrode surface even when steel electrodes are used [44].

In addition, direct anodic oxidation of organics (Org.) by electron transfer (equation (11)) could be realized to produce a product (P) [46]:

$$
\text { Org }_{a d s}-z e^{-} \rightarrow P_{a d s}
$$

Another possibility is proceeding of a mediated / indirect oxidation via electrogenerated active species at the insoluble anode [47]. 
The oxygen evolution reaction on the anode involves the initial formation of physisorbed $\bullet \mathrm{OH}$ as intermediate species - equation (12). M represents anode material.

$$
\mathrm{M}+\mathrm{H}_{2} \mathrm{O} \rightarrow \mathrm{M}(\bullet \mathrm{OH})+\mathrm{H}^{+}+e^{-}
$$

In the case of catalytic anodes the formed $\mathrm{M}(\bullet \mathrm{OH})$ species are oxidized to chemisorbed "active oxygen" MO with a higher oxidation state of the metal M, which attacks the organic pollutants to transform them into $\mathrm{CO}_{2}$ - equation (13):

$$
a M(\bullet O H)+R \rightarrow M+m \mathrm{CO}_{2}+n \mathrm{H}_{2} \mathrm{O}+x \mathrm{H}++y e^{-}
$$

where the organic $\mathrm{R}$ contains $\mathrm{m}$ carbon atoms and to be completely mineralized it needs $\mathrm{a}=$ $(2 \mathrm{~m}+\mathrm{n})$ oxygen atoms [47].

Removal efficiency was calculated by equation (14):

$$
R, \%=\left(C_{o}-C\right) \times 100 / C_{o}
$$

where $\mathrm{R}(\%)$ is the removal efficiency, and $\mathrm{C}_{\mathrm{o}}(\mathrm{mg} / \mathrm{L})$ and $\mathrm{C}(\mathrm{mg} / \mathrm{L})$ are the initial and final concentrations of the pollutant.

\section{Materials and methods}

Recycled clarified water taken from a lead-zinc flotation enterprise was used in the water conditioning experiments - Table 1. The enterprise recorded deterioration of the flotation results when increased the share of recycled water in the process. Concentrations of $\mathrm{Ca}^{2+}$ and $\mathrm{Mg}^{2+}$ were determined by titration with EDTA disodium salt solution, concentration of $\mathrm{HCO}_{3}^{-}$- by titration with $\mathrm{HCl}$ solution, concentration of $\mathrm{Cl}^{-}$was found by Mohr's method, and $\mathrm{SO}_{4}{ }^{2-}$ concentration was determined by Turbidimetry. Concentration of $\mathrm{Na}^{+}$, as well as concentration of lead and zinc in obtained concentrates (after digestion of solid samples) were analyzed by ICP-AES. The $\mathrm{pH}$ value and conductivity of water were measured by applying electrometric methods - WTW Multi 340i/SET device and combined electrodes were used. Dissolved organic carbon (DOC) as an integral parameter for determining the organic compounds concentration in liquid phase, was measured by catalytic combustion method (with Pt catalyst, at $680{ }^{\circ} \mathrm{C}$ ). SHUMATZU model TOC-VCSH analyzer was used, and the standard ISO 20236:2018 [48] was followed. Spectroquant NOVA 60 and a Merck COD cell test were used to find the Chemical oxygen demand (COD). Samples were preliminary digested by using a Spectroquant TR420 device. The method is very similar to DIN38409-41-2, DIN ISO 1575 and is analogous to EPA410.4 and APHA 5220 D.

Water $(1600 \mathrm{~mL})$ treatment was carried out in $2 \mathrm{~L}$ beaker where sets of plate-shaped cathodes and anodes made of different materials were introduced (in parallel monopolar connection, electrode distance $-3 \mathrm{~cm}$ ). In experiments where EO was aimed as the main electrochemical processes, the anode was made of preliminary passivated titanium $\left(\mathrm{Ti}, \mathrm{TiO}_{2}\right)$. In experiments where $\mathrm{EC}$ was aimed as the main electrochemical processes, the anode was made of mild steel (MS). In both cases the cathode was stainless (ASTM 316) steel (SS). Mixing was ensured with SK-O180-E shaker. Electrodes were connected with a rectifier with inbuilt A-meter and V-meter. Experiments were performed in batch mode of operation. Before each run, the electrodes were cleaned, rinsed and dried with filter paper.

Current density is an influential operating parameter in controlling the rate of an electrochemical reaction. It determines the production rate of ions forming the coagulant, the flock growth, the hydrogen bubble production rate and their size (related to the effectiveness of the EF, supplementing both EC and EO), the mass transfer of the generated metallic flocs [31, 45]. The range of the optimum current densities and treatment times reported in the literature is large, i.e. 5 - $300 \mathrm{~min}$ and $0,2-70 \mathrm{~mA} / \mathrm{cm}^{2}$ [31-35, 43, 45, 49]. 
Based on our experience [36, 37] and on many of literature cases, we have applied several treatment times $(5,10,15$ and $20 \mathrm{~min})$ and current densities $(2,4,6,8$ and 10 $\mathrm{mA} / \mathrm{cm}^{2}$ ).

The natural water $\mathrm{pH}$ value was not changed before the treatment since in a real process this would be an additional operation with its corresponding costs. The foam formed was removed manually from the upper part of the reactor. The treated water was kept in the reactor for $5 \mathrm{~min}$. Then the treated clear water was separated by filtration from the sludge precipitated on the bottom. Water from 6 parallel experiments was collected, mixed, subjected to analysis and further used in the flotation experiments.

Bench-scale open cycle flotation studies were conducted. Lead-zinc ore $(500 \mathrm{~g})$ containing $\mathrm{Pb}-4,32 \%, \mathrm{Zn}-4,62, \mathrm{Fe}-17,26 \%$ was used in laboratory experiments. It was milled till achieving $\geq 80 \%$ less than $0,127 \mathrm{~mm}$. Mechanober laboratory flotation machine with cell of $1 \mathrm{~L}$ was applied. Used reagents were $\mathrm{ZnSO}_{4}(240 \mathrm{~g} / \mathrm{t}), \mathrm{CuSO}_{4}(180 \mathrm{~g} / \mathrm{t})$, $\mathrm{NaHCO}_{3}(450 \mathrm{~g} / \mathrm{t}), \mathrm{NaCN}(30 \mathrm{~g} / \mathrm{t})$, isobuthyl xanthate $(120 \mathrm{~g} / \mathrm{t}), \mathrm{Na}_{2} \mathrm{~S}(80 \mathrm{~g} / \mathrm{t})$, and pine oil $(40 \mathrm{~g} / \mathrm{t})$. In lead cycle the time for rough flotation was $4 \mathrm{~min}$, and for the first and second scavenger flotation - 3 and 2 min correspondingly. The times in zinc cycle were 4 min in rough flotation and 3 and $2 \mathrm{~min}$ correspondingly for the first and second scavenger flotation. Experiments (two parallel) were carried out with fresh tap water, recycled clarified water taken from the mentioned lead-zinc flotation enterprise and electrochemically conditioned recycled clarified water.

\section{Results and discussion}

Results from water treatment under different conditions are presented in figures 1 and 2 and Table 1.

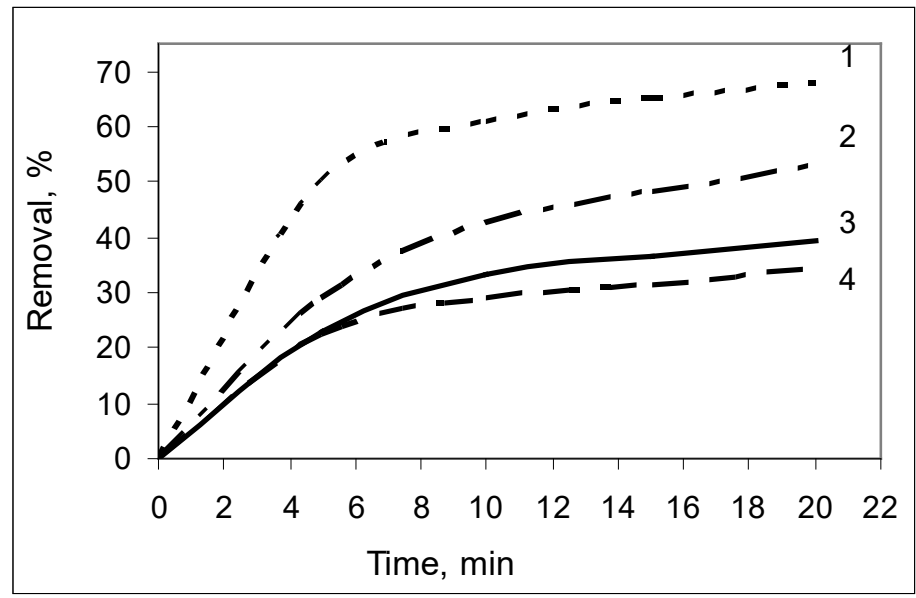

Fig. 1. Impact of time on pollutants removal at $5 \mathrm{~mA} / \mathrm{cm}^{2}: 1$ - COD removal with SS/MS; 2 - COD removal with $\mathrm{SS} / \mathrm{Ti}, \mathrm{TiO}_{2} ; 3$ - DOC removal with $\mathrm{SS} / \mathrm{Ti}, \mathrm{TiO}_{2} ; 4$ - DOC removal with SS/MS

As it can be seen from figures 1 and 2 the electrochemical treatment (both with soluble an insoluble anodes) of the process wastewater leads to a decrease in COD and DOC. It has to be added that with both type of electrodes some pollutants were carried out to the beaker surface by the small gas bubbles formed (by reactions (2) or (7)), i.e. both EO and EC were aided by EF. 
The process is fast in the initial 5-10 min and further, with the time increase, the removal increases slowly. A similar course of the process was observed by other authors $[31,34,50]$ although sometimes in considerably longer time, as found by $\mathrm{Wu}$ at al. [31]. The same authors achieved around $65 \%$ COD removal from mineral processing wastewater with iron sacrificial anode (at $\left.90 \mathrm{~mA} / \mathrm{cm}^{2}, 60 \mathrm{~min}, \mathrm{pH} 6,5\right)$ and the most notable increase in the COD removal was the initial $20 \mathrm{~min}$.

Figure 2 shows that initially the pollutants removal increased significantly with increasing the current density, while at higher current densities (in the studied interval) practically a plateau is reached. Such effect have been observed by different authors - as plateau formation in the dependence "pollutants removal as function of current density" [ 31 , $35,47]$ and even as a decrease in the removal with an increase in current density after a given value [34].

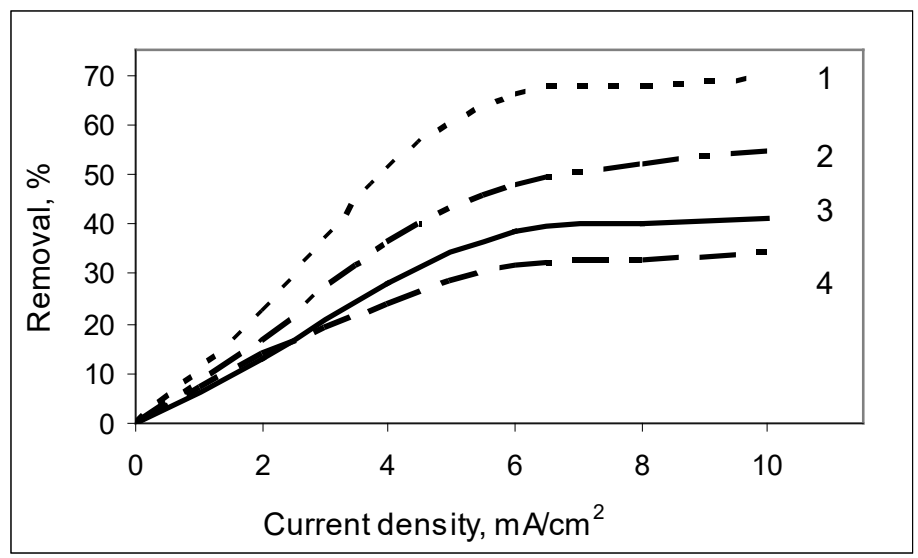

Fig. 2. Impact of current density on pollutants removal at 10 min treatment time: 1 - COD removal with SS/MS; 2 - COD removal with SS/ $\mathrm{Ti}_{1}, \mathrm{TiO}_{2} ; 3$ - DOC removal with $\mathrm{SS} / \mathrm{Ti}, \mathrm{TiO}_{2} ; 4$ - DOC removal with SS/MS

Different current densities were reported as optimal by different authors [31-35, 43,45, 49] depending of the nature of sacrificial anodes, nature and concentration of pollutants, water $\mathrm{pH}$ and conductivity. Although the applied current generally corresponds to the release of ions in the solution (through the Faraday's law), an excess of current may negatively affect the efficiency of EC by enabling secondary reactions, temperature increase, etc.

As it can be seen from figures 1 and 2, COD removal is higher than the DOC removal. The finding is not unexpected, since the COD "catches" all chemically oxidizable pollutants that present in water (including inorganic species), while DOC is a part of the total organic carbon available in the water. A similar difference in the decrease of COD and DOC due to oxidation reactions was observed also by $\mathrm{Fu}$ and co-authors [21]. They have found that at removal of thiol collectors $>90 \%$, the removal of COD was approximately $62 \%$ and the carbon mineralization (followed by TOC analysis) was about $27 \%$.

The organics removal resulting from treatment with an insoluble anode (presumably due mainly to electrooxidation) is lower compared to that resulting from treatment with a soluble anode, i.e. when the main process was electrocoagulation. Similar effect was observed by Zhang and co-authors [50]. They found that TOC removal from fracturing flowback water, achieved by EC, is significantly higher compared to EO (with Pt anode). In 3 hours of treatment the TOC removal was $32 \%$ when EO was applied, compared to $\sim 76 \%$ when EC was carried out, and the TOC removal by EC was $70 \%$ in $30 \mathrm{~min}$. 
Probably the good results obtained by EC with mild steel electrodes are related with the main proceeding anodic reaction (5) and the subsequent coagulant formation - reaction (6). However, with increasing the current density (that means also the cell voltage) reactions (7) and (8) can not be excluded. Oxygen formed, together with the oxygen naturally dissolved in water, may further oxidize $\mathrm{Fe}(\mathrm{II})$ to $\mathrm{Fe}(\mathrm{III})$ to form $\mathrm{Fe}(\mathrm{OH})_{3(\mathrm{~S})}[44,45]$ :

$$
4 \mathrm{Fe} 2++10 \mathrm{H} 2 \mathrm{O}+\mathrm{O} 2(\mathrm{~g}) \rightarrow 4 \mathrm{Fe}(\mathrm{OH}) 3(\mathrm{~s})+8 \mathrm{H}+
$$

and protons formed can be neutralized with the $\mathrm{OH}^{-}$produced in reaction (2).

In addition, at higher voltages iron(III) species could be directly electrogenerated from the sacrificial anode by direct charge transfer reaction (16):

$$
\mathrm{Fe}^{o} \rightarrow \mathrm{Fe}^{3+}+3 e^{-}
$$

Both $\mathrm{Fe}(\mathrm{OH})_{2}$ and $\mathrm{Fe}(\mathrm{OH})_{3}$ are insoluble and can act as in situ generated coagulants. The iron(III) species possess higher charge density, compared to Fe(II), favoring the coagulation-flocculation process thus being more effective at smaller doses. In addition, different oxyhydroxides (such as green rust - GR, $\alpha-\mathrm{FeOOH}$ and $\gamma-\mathrm{FeOOH}$ ) may be formed that can function as coagulating and flocculating reagents. GR possesses larger specific surface area and reactivity compared to iron hydroxides. Polar non-charged compounds are absorbed into the interlayer structure of GR [44].

Based on the data on the influence of treatment time and current density on the pollutants removal (Figures 1 and 2) a 10 min treatment with mild steel anode at current density of $6 \mathrm{~mA} / \mathrm{cm}^{2}$ could be considered as optimal. Wastewater treatment under these conditions was carried out 6 times. Treated water was separated from the solid phase and mixed in order to gather enough amount for the flotation experiments. Some parameters of the treated water are presented in Table 1.

Table 1. Some parameters of used and treated water.

\begin{tabular}{|c|c|c|c|}
\hline Parameter & Fresh $\mathbf{H}_{\mathbf{2}} \mathbf{O}$ & Recycled $\mathbf{H}_{\mathbf{2}} \mathbf{O}$ & Treated* recycled $\mathbf{H}_{\mathbf{2}} \mathbf{O}$ \\
\hline $\mathrm{Ca}^{2+}, \mathrm{mg} / \mathrm{L}$ & 43,2 & 170,5 & 156,9 \\
\hline $\mathrm{Mg}^{2+}, \mathrm{mg} / \mathrm{L}$ & 3,4 & 6,6 & 5,4 \\
\hline $\mathrm{Na}^{+}+\mathrm{K}^{+}, \mathrm{mg} / \mathrm{L}$ & 29,2 & 52,5 & 53,6 \\
\hline $\mathrm{Fe}_{\text {tot }}, \mathrm{mg} / \mathrm{L}$ & 0,15 & 5,8 & 7,3 \\
\hline $\mathrm{HCO}_{3}^{-}, \mathrm{mg} / \mathrm{L}$ & 119,2 & 137,8 & 134,3 \\
\hline $\mathrm{Cl}^{-}, \mathrm{mg} / \mathrm{L}$ & 19,1 & 57,3 & 41,2 \\
\hline $\mathrm{SO}_{4}^{2-}, \mathrm{mg} / \mathrm{L}$ & 64,5 & 309,8 & 311,3 \\
\hline $\mathrm{pH}$ & 7,6 & 8,9 & 8,5 \\
\hline$\chi, \mu \mathrm{S} / \mathrm{cm}$ & 303 & 815 & 778 \\
\hline $\mathrm{COD}, \mathrm{mg} / \mathrm{L}$ & 6,2 & 126,1 & 42,7 \\
\hline $\mathrm{DOC}, \mathrm{mg} / \mathrm{L}$ & 1,2 & 57,3 & 39,1 \\
\hline
\end{tabular}

* at optimal conditions

As it can be seen, the main parameters influenced by the treatment were COD, DOC, $\mathrm{Ca}^{2+}$ and $\mathrm{Cl}^{-}$- concentrations of all of them decreased to a certain degree. A decrease in the concentration of $\mathrm{Ca}^{2+}$, along with COD degrease by electrocoagulation, was observed also 
by $\mathrm{Wu}$ and co-authors [31] and explained by probable $\mathrm{Ca}^{2+}$ encapsulation in flocs formed by EC.

The small amount of $\mathrm{Cl}^{-}$ions removed could be assigned either to reaction (8) or to their inclusion in eventually formed green rust.

Averaged data from flotation experiments are presented in Table 2.

Table 2. Results from flotation experiments.

\begin{tabular}{|c|c|c|c|}
\hline Parameter & With fresh $\mathbf{H}_{\mathbf{2}} \mathbf{O}$ & With recycled $\mathbf{H}_{\mathbf{2}} \mathbf{O}$ & With treated recycled $\mathbf{H}_{\mathbf{2}} \mathbf{O}$ \\
\hline $\mathrm{Pb}$ concentrate & \multicolumn{3}{|l|}{} \\
\hline $\mathrm{Pb}$ content, $\%$ & 68,19 & 65,92 & 67,57 \\
\hline $\mathrm{Zn}$ content, \% & 5,42 & 5,95 & 5,56 \\
\hline $\mathrm{Pb}$ recovery, \% & 90,45 & 87,52 & 89,10 \\
\hline $\mathrm{Zn}$ concentrate & \multicolumn{3}{|}{} \\
\hline $\mathrm{Zn}$ content, $\%$ & 48,90 & 45,97 & 47,03 \\
\hline $\mathrm{Pb}$ content, $\%$ & 2,07 & 3,58 & 2,24 \\
\hline $\mathrm{Zn}$ recovery, \% & 76,16 & 72,23 & 75,43 \\
\hline
\end{tabular}

As it can be seen from Table 2, the use of recycled untreated water can lead to deterioration of flotation results, in comparison to the case where fresh tap water was used. Utilization of the same recycled water but after the electrochemical conditioning mitigates the situation. The flotation results obtained are improved compared to the results when untreated water was used. They are near to the results obtained with tap water.

Although found by us difference in the flotation results obtained with untreated and treated process wastewater is not so big as found by other authors [33, 36], it deserves consideration since in flotation every percent matters.

Even more, unlike other authors, we worked with cheap mild steel electrodes, at lower current density and shorter time which means less electricity consumption and lower cost of sacrificial anode material.

\section{Conclusions}

Based on the results obtained the following conclusions can be drawn.Direct reuse in leadzinc flotation of clarified wastewater from the flotation process can deteriorate the flotation results.

Electrochemical conditioning of that wastewater is able to decrease the COD and DOC of the treated water. Electrocoagulation with mild steel sacrificial anodes, complemented by electroflotation showed better results compared to electrooxidation with $\mathrm{Ti} / \mathrm{TiO}_{2}$ insoluble anode complemented by electroflotation. At optimum conditions (in the studied range) 66 $\%$ of COD and nearly $32 \%$ of DOC were removed by electrocoagulation with mild steel electrodes at energy consumption of $0,458 \mathrm{kWh} / \mathrm{m}^{3}$.

Treated water ensured better results of lead-zinc flotation than untreated and comparable with the results found when the process was carried out with fresh tap water.

Electrocoagulation with mild steel electrodes gives promising results for treating wastewater from lead-zinc flotation (before this water is returned back to the flotation process) and deserves further investigation. 


\section{References}

1. Rossana-Brantes, A., \& Olivares, G. (2008). Best practices and efficient use of water in the mining industry, Chilean Copper Commission, Quebecor World Chile.

2. Jennett, J., \& Wixson, B. (1983). Geochemistry, mining and the environment. Minerals and the Environment, 5, 39-53. https://doi.org/10.1007/BF02084895

3. Meng, X., Wu, J., Kang, J., Gao, J., Liu, R., Gao, Y., Wang, R., Fan, R., Khoso, S. A., Sun, W., \& Hu Y. (2018). Comparison of the reduction of chemical oxygen demand in wastewater from mineral processing using the coagulation-flocculation, adsorption and Fenton processes. Minerals Engineering, 128, 275-283. https://doi.org/10.1016/j.mineng.2018.09.009

4. Gunson, A. J., Klein, B., Veiga, M., \& Dunbar, S. (2012). Reducing mine water requirements. Journal of Cleaner Production, 21(1), 71-82. https://doi.org/10.1016/j.jclepro.2011.08.020

5. USGS. (2016). Water Science School. https://www.usgs.gov/special-topic/water-scienceschool/science/surface-water

6. United Nations World Water Assessment Programme. (2018). The United Nations World Water Development Report 2018: Nature-Based Solutions for Water, UNESCO, Paris

7. Neumann M. (2018). Challenges and opportunities in the path towards sustainable development of mineral resources. EGRC 9th session - UNECE, Geneva

8. Xu, Y, Lay, J. P. \& Korte F. (1988). Fate and effects of xanthates in laboratory freshwater systems. Bulletin of Environmental Contamination and Toxicology, 41(5), 683-689. https://doi.org/10.1007/BF02021019

9. Boening, D. W. (1998). Aquatic toxicity and environmental fate of xanthates. SME Transactions, 304, 50-57.

10. Panayotov, V., \& Panayotova, M. (2019). Sustainable use of water in mining and mineral processing. In V. Kalinichenko \& R. Moraru (Eds.) Sustainable development of resource-saving technologies in mineral mining and processing. (pp. 214-243). UNIVERSITAS Publishing, Petroșani, Romania

11. Rao, S., \& Finch, J. (1989). A review of water re-use in flotation. Minerals Engineering, 2, 6585. https://doi.org/10.1016/0892-6875(89)90066-6

12. Johnson, N.W. (2003). Issue in maximization of recycling of water in a mineral processing plant. In Proceedings of the Water in mining conference (pp. 239-245), Brisbane, Australia,13-15 Oct 2003

13. Nedved M., \& Jansz, J. (2006). Waste water pollution control in the Australian mining industry. Journal of Cleaner Production, 14 (12-13), 1118-1120. https://doi.org/10.1016/j.jclepro.2005.03.008

14. Liu, W., Moran, C. J., \& Vink. S. (2013). A review of the effect of water quality on flotation. Minerals Engineering, 53, 91-100. https://doi.org/10.1016/j.mineng.2013.07.011

15. Shengo, L. M., \& Mutiti, W. N. C. (2016). Bio-treatment and water reuse as feasible treatment approaches for improving wastewater management during flotation of copper ores. International Journal of Environmental Science and Technology, 13, 2505-2520. DOI 10.1007/s13762-0161073-5

16. Levay, G., Smart, R., \& Skinner., W. (2001). The impact of water quality on flotation performance. Journal of the Southern African Institute of Mining and Metallurgy, 111, 69-76 III-IV. https://doi.org/10.1016/S1003-6326(08)60294-0

17. Chen J.-m., Liu R.-q., Sun, W., \& Qiu, G.-z. (2009). Effect of mineral processing wastewater on flotation of sulfide minerals. Transactions of Nonferrous Metals Society of China, 19(2), 454457. https://doi.org/10.1016/S1003-6326(08)60294-0

18. Sandenbergh R. F., \& Wei, Y. (2007). The influence of water quality on the flotation of the Rosh Pinah complex lead-zinc sulfides. Proc. of the 4th Southern African Conference on base metals. (pp. 45-55) The South African Institute of Mining and Metallurgy, SA 
19. Lin, S., Liu, R., Wu, M., Hu, Y., Sun, W., Shi, Z., Han, H., \& Li, W. (2020). Minimizing beneficiation wastewater through internal reuse of process water in flotation circuit. Journal of Cleaner Production, 245. https://doi.org/10.1016/j.jclepro.2019.118898

20. Ikumapayi, F., \& Rao, K. H. (2015). Recycling process water in complex sulfide ore flotation: effect of calcium and sulfate on sulfide minerals recovery. Mineral Processing and Extractive Metallurgy Review, 36 (1), 45-64. https://doi.org/10.1080/08827508.2013.868346

21. Fu, P., Lin, X., Li, G., Chen Z., \& Peng, H. (2018). Degradation of Thiol Collectors Using Ozone at a Low Dosage: Kinetics, Mineralization, Ozone Utilization, and Changes of Biodegradability and Water Quality Parameters. Minerals, 8, 477. https://doi.org/10.3390/min 8110477

22. Li, M., Zhong, H., He, Z., Hu, L., Sun, W., Loganathan, P., \& Xiong, D. (2020). Degradation of various thiol collectors in simulated and real mineral processing wastewater of sulfide ore in heterogeneous modified manganese slag/PMS system. Chemical Engineering Journal, https://doi.org/10.1016/j.cej.2020.127478

23. Park, J., Han, Y.-S., \& Ji, S.-W. (2018). Investigation of Mineral-Processing Wastewater Recycling Processes: A Pilot Study. Sustainability, 10(9), 3069. https://doi.org/10.3390/su10093069

24. Rezaei, R., Massinaei, M., \& Zeraatkar Moghaddam, A. (2018). Removal of the residual xanthate from flotation plant tailings using modified bentonite. Minerals Engineering, 119, 1-10. https://doi.org/10.1016/j.mineng.2018.01.012

25. Lin, W. X., Tian, J., Ren, J., Xu, P.T., Dai, Y.K., Sun, S.Y., \& Wu, C. (2016). Oxidation of aniline aerofloat in flotation wastewater by sodium hypochlorite solution. Environmental Science and Pollution Research, 23, 785-792. https://doi.org/10.1007/s11356-015-5319-4

26. Meng, X., Khoso, S. A., Lyu, F., Wu, J., Kang, J., Liu, H., Zhang, Q., Han, H., Sun, W., \& Y. $\mathrm{Hu},(2019)$. Study on the influence and mechanism of sodium chlorate on COD reduction of minerals processing wastewater. Minerals Engineering, 134, 1-6. https://doi.org/10.1016/j.mineng.2019.01.009

27. Meng, X., Khoso, S. A., Wu, J., Tian, M., Kang, J., Liu, H., Zhang, Q., Sun, W., \& Hu, Y. (2019). Efficient COD reduction from sulfide minerals processing wastewater using Fenton process. Minerals Engineering, 132, 110-112. https://doi.org/10.1016/j.mineng.2018.11.054

28. Chen, S. H., Gong, W.Q., Mei, G.J., Zhou, Q., Bai, C.P., \& Xu, N. (2011). Primary biodegradation of sulfide mineral flotation collectors. Minerals Engineering, 24, 953-955. https://doi.org/10.1016/j.mineng.2011.01.003

29. Jafari, M., Shafaei, S. Z. A., Abdollahi, H., Gharabaghi, M., \& Chelgani, S. C. (2017). A comparative study on the effect of flotation reagents on growth and iron oxidation activities of Leptospirillum ferrooxidans and Acidithiobacillus ferrooxidans. Minerals, 7(1), 2. https://doi.org/10.3390/min7010002

30. Liu, R. Q., Sun, W., Ouyang, K., Zhang, L. M., \& Hu, Y. H. (2015). Decomposition of sodium butyl xanthate (SBX) in aqueous solution by means of OCF: Ozonator combined with flotator. Minerals Engineering, 70, 222-227. https://doi.org/10.1016/j.mineng.2014.09.020

31. Wu, M., Hu, Y., Liu, R., Lin, S., Sun, W., \& Lu, H. (2019). Electrocoagulation method for treatment and reuse of sulphide mineral processing wastewater: Characterization and kinetics. Science of the Total Environment, 696, 134063. https://doi.org/10.1016/j.scitotenv.2019.134063

32. Mamelkina, M. A., Tuunila, R., Sillänpää, M., \& Häkkinen, A. (2019). Systematic study on sulfate removal from mining waters by electrocoagulation. Separation and Purification Technology, 216, 43-50. https://doi.org/10.1016/j.seppur.2019.01.056

33. Mamelkina, M. A., Vasilyev, F., Tuunila, R., Sillänpää, M., \& Häkkinen, A. (2019). Investigation of the parameters affecting the treatment of mining waters by electrocoagulation. Journal of Water Process Engineering, 32, Article 100929. https://doi.org/10.1016/j.jwpe.2019.100929

34. Jing, G., Ren, S., Gao, Y., Sun, W., \& Gao, Z. (2020). Electrocoagulation: a promising method to treat and reuse mineral processing wastewater with high COD. Water, 12, Article 134063. https://doi.org/10.3390/w12020595 
35. Das, D., \& Nandi B. K. (2021). Treatment of iron ore beneficiation plant process water by electrocoagulation. Arabian Journal of Chemistry, 14, Article 102902. https://doi.org/10.1016/j.arabjc.2020.11.008

36. Panayotova, M., \& Panayotov, V. (2004). An electrochemical method for decreasing the concentration of sulfate and molybdenum ions in industrial wastewater. Journal of Environmental Science and Health, Part A, A39(1), 173-183. https://doi.org/10.1081/ese$\underline{120027376}$

37. Panayotov, V., Panayotova, M., Mitrov, Ts., Gock, E., \& Zommer, P. (2001). Heavy metals removal from wastewater through electrochemical treatment. Journal of Chemical Technology and Metallurgy, XXXVI, 1, 81-86.

38. Panayotov V., \& Panayotova M., (2006). Electrochemical selection of polymetallic ores. In G. Onal (Ed.) Proc. XXIII International Mineral Processing Congress (pp. 675-677). IMPC

39. Körbahti, B. K. \& Artut, K. (2010). Electrochemical oil/water demulsification and purification of bilge water using $\mathrm{Pt} / \mathrm{Ir}$ electrodes. Desalination, 258(1-3), 219-228. https://doi.org/10.1016/j.desal.2010.03.008

40. Vepsälänen, M, Pulliainen, M, \& Sillanpää, M. (2012). Effect of electrochemical cell structure on natural organic matter (NOM) removal from surface water through electrocoagulation (EC). Separation and Purification Technology, 99, 20-27. https://doi.org/10.1016/j.seppur.2012.08.011

41. An, C., Huang, G., Yao, Y., \& Zhao, S. (2017). Emerging usage of electrocoagulation technology for oil removal from wastewater: A review. Science of the Total Environment, 579, 537-556. https://doi.org/10.1016/j.scitotenv.2016.11.062

42. Changmai, M., Pasawan, M., \& Purkait, M. K. (2019). Treatment of oily wastewater from drilling site using electrocoagulation followed bymicrofiltration. Separation and Purification Technology, 210, 463-472. https://doi.org/10.1016/j.seppur.2018.08.007

43. Nidheesh, P.V., Scaria, J., Babu, D. S., \& Kumar, M. S. (2021). An overview on combined electrocoagulation-degradation processes for the effective treatment of water and wastewater. Chemosphere, 263, Article 127907. https://doi.org/10.1016/j.chemosphere.2020.127907

44. Tegladza, I. D., Xu, Q., Xu, K., Lv, G., \& Lu J. (2021). Electrocoagulation processes: A general review about role of electro-generated flocs in pollutant removal. Process Safety and Environmental Protection, 146 169-189. https://doi.org/10.1016/j.psep.2020.08.048

45. Garcia-Segura, S., Eiband, M. M. S.G., de Melo, J. V., \& Martínez-Huitle, C. A. (2017). Electrocoagulation and advanced electrocoagulation processes: A general review about the fundamentals, emerging applications and its association with other technologies. Journal of Electroanalytical Chemistry, 801, 267-299. http://dx.doi.org/10.1016/j.jelechem.2017.07.047

46. Ganiyu, S. O., Martínez-Huitle, C. A., \& Oturan, M. A. (2021). Electrochemical advanced oxidation processes for wastewater treatment: Advances in formation and detection of reactive species and mechanisms. Current Opinion in Electrochemistry, 27, Article 100678. https://doi.org/10.1016/j.coelec.2020.100678

47. Brillas, E. (2021). Recent development of electrochemical advanced oxidation of herbicides. A review on its application to wastewater treatment and soil remediation. Journal of Cleaner Production, 290, Article 125841. https://doi.org/10.1016/j.jclepro.2021.125841

48. ISO 20236:2018 Water quality - Determination of total organic carbon (TOC), dissolved organic carbon $(\mathrm{DOC})$, total bound nitrogen $(\mathrm{TNb})$ and dissolved bound nitrogen $(\mathrm{DNb})$ after high temperature catalytic oxidative combustion, 02-Oct-2018.

49. Shahedi, A., Darban, A. K., Taghipour, F., \& Jamshidi-Zanjani, A. (2020). A review on industrial wastewater treatment via electrocoagulation processes. Current Opinion in Electrochemistry, 22, 154-169 https://doi.org/10.1016/j.coelec.2020.05.009

50. Zhang, Y., Zhao, E., Cui, X., Zhu, W., Han, X., Yu, G., \& Wang, Y. (2021). Removal of organic compounds from shale gas fracturing flowback water by an integrated electrocoagulation and electro-peroxone process. Separation and Purification Technology, 265, Article 118496 https://doi.org/10.1016/j.seppur.2021.118496 